\title{
Regulations Governing the Usage of Reclaimed Water as an Alternative Water Source for Agricultural Irrigation in Florida ${ }^{1}$
}

\author{
Leticia Braune, Gulcan Onel, Tatiana Borisova, and Pilar Useche ${ }^{2}$
}

\section{Abstract}

Freshwater is becoming increasingly scarce as the global population grows rapidly. Given the severe threat that water scarcity poses to food security and the economy, reclaimed water from alternative sources can be used to help offset the demand for freshwater in agriculture and other sectors. To ensure that pathogenic or trace chemical constituents in reclaimed water do not pose a threat to human health and the environment, state and federal governments impose regulations governing reclaimed water use. This fact sheet documents the rules and regulations governing the use of reclaimed water in Florida agriculture. Target audiences include growers exploring alternative water use for agriculture, Extension agents, and the public.

Acknowledgment: This project was supported by Agriculture and Food Research Initiative Competitive Grant no. 2018-67016-27578 awarded as a Center of Excellence from the USDA National Institute of Food and Agriculture.

\section{Introduction}

The global population is rapidly increasing, resulting in an unavoidable rise in demand for water. In many parts of the world, groundwater is being depleted due to withdrawal rates that far surpass replenishment rates (Postel 2000). The severe threat that water scarcity poses to food security and the economy has received increasing global attention in the last decade. Since agriculture accounts for the largest share of total water withdrawals, with $70 \%$ of global water withdrawals being used for irrigation of croplands (FAO n.d.), the question of how to decrease vulnerability to water shortage in agriculture is of critical concern.

To address the issue of declining freshwater availability from groundwater and surface water sources, many industries have turned to alternative water sources to help offset the demand for fresh water. Examples of such alternatives include seawater, rainwater, stormwater, brackish water, non-fresh surface water, and reclaimed water. Reclaimed water, also referred to as recycled or reused water, is former wastewater that has been recovered from domestic, commercial, and industrial sources and treated to remove impurities so it can be reused for other beneficial purposes. Reclaimed water is considered safe for most non-drinking and non-sanitary purposes (Toor and Lusk 2011b).

Given the negative impacts that water scarcity can have on cropland productivity, there are incentives for farmers to seek alternatives to the use of fresh surface water and groundwater-and they have done so. Reclaimed water has been safely and successfully used for crop irrigation in the United States for over 50 years, especially in Florida and California (Toor and Lusk 2011b).

1. This document is FE1091, one of a series of the Food and Resource Economics Department, UF/IFAS Extension. Original publication date January 2021. Visit the EDIS website at https://edis.ifas.ufl.edu for the currently supported version of this publication.

2. Leticia Braune, graduate student; Gulcan Onel, assistant professor; Tatiana Borisova, associate professor and Extension specialist; and Pilar Useche, associate professor; Food and Resource Economics Department, UF/IFAS Extension, Gainesville, FL 32611.

The Institute of Food and Agricultural Sciences (IFAS) is an Equal Opportunity Institution authorized to provide research, educational information and other services

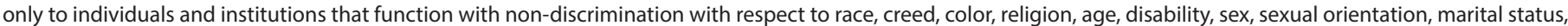

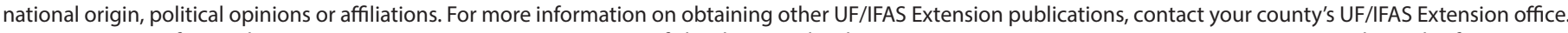
U.S. Department of Agriculture, UF/IFAS Extension Service, University of Florida, IFAS, Florida A \& M University Cooperative Extension Program, and Boards of County Commissioners Cooperating. Nick T. Place, dean for UF/IFAS Extension. 
To ensure that no threats are posed to human health and the environment, governments have different regulations governing reclaimed water use. Some of the major concerns associated with using reclaimed water for agricultural irrigation include direct and indirect contamination of crops, survival of pathogenic constituents, and the uptake of trace chemical constituents (Takashi et al. 2007). While the US Environmental Protection Agency (EPA) establishes guidelines for water reuse, it encourages states to develop their own regulations. As a result, the regulations set by some US states, such as Florida and California, are more stringent than the World Health Organization guidelines, which have been widely adopted in Europe and other regions throughout the world (Parsons et al. 2010). In addition to the EPA guidelines, the US Food and Drug Administration (FDA) has set additional requirements for the quality of water when water is used for irrigation of food crops. This study outlines the federal guidelines and Florida regulations for the use of reclaimed water for agricultural irrigation. Target audiences include growers exploring alternative water use for agriculture, Extension agents, and the general public.

\section{Federal Water Reuse Guidelines and Regulations}

\section{The EPA Guidelines}

Instead of establishing national standards for water reuse, the EPA decided to develop comprehensive federal guidelines and encourage states to develop their own regulations. Although there are no federal regulations governing reclaimed water use, EPA guidelines are meant to "serve as an authoritative reference on water reuse practices" (EPA 2012).

The EPA uses the "Fit for Purpose" approach, which "provides a framework for cost-effective treatment to be applied to a water source sufficient to meet the quality appropriate for the intended use" (EPA 2012). This means that there are different guidelines for the use of reclaimed water to irrigate food and non-food crops. Food crops are intended for human consumption and can be further divided into crops that will be commercially processed and crops that will be consumed raw. The guidelines for commercially processed food crops, which are those that have undergone chemical or physical processing sufficient to destroy pathogens prior to sale to the public, are the same as for non-food crops. Irrigation of non-food crops include fodder, fiber, and seed crop irrigation as well as irrigation in pasturelands, commercial nurseries, and sod farms. Table 1 summarizes the EPA guidelines for water reuse for irrigation. Recommended water quality criteria for irrigation are provided in Table 2 . In addition to these guidelines, the EPA also adds that the reclaimed water should not contain measurable levels of pathogens. Monitoring for specific pathogens may become a part of the standard testing protocol as the use of reclaimed water for indirect potable reuse applications becomes more common (Haering et al. 2009).

As shown in Table 1, secondary treatment is recommended for both categories under agricultural reuse (the first category comprised of non-processed, raw food crops and the second category comprised of processed food crops and non-food crops). Secondary treatment includes activated sludge processes, trickling filters, and rotating biological contractors and may include stabilization pond systems. Disinfection, which is recommended for all crops, is defined as "the destruction, inactivation, or removal of pathogenic microorganisms by chemical, physical, or biological means" (EPA 2012) and can be achieved by chlorination, ozonation, other chemical disinfectants, ultraviolet (UV) light, membrane processes, or other processes. For non-processed food crops, filtration is also recommended. Filtration refers to "the passing of wastewater through natural undisturbed soils or filter media such as sand and/ or anthracite; or the passing of wastewater through microfilters or other membrane processes" (EPA 2012). Chemical (coagulant and/or polymer) addition prior to filtration may be necessary to meet water quality standards.

Recommended limits concerning water quality apply to reclaimed water at the point of discharge from the treatment facility. For both crop categories, the recommended $\mathrm{pH}$ is between 6 and 9 , and the recommended level of residual chlorine is at least $1 \mathrm{mg} / \mathrm{Cl}_{2}$. The latter applies only when chlorine is used as the primary disinfection chemical. The total chlorine residual should be met after an actual modal contact time of at least 90 minutes. In other words, water should be exposed to the disinfectant for at least 90 minutes. In some cases, higher chlorine residual and/or a longer contact time may be necessary to ensure that viruses and parasites are inactivated or destroyed. Less contact time can be applied if it has been demonstrated to provide equivalent levels of indicator organism and pathogen reduction, but it should always be at least 30 minutes. It is important to note that most plants are severely damaged when chlorine concentrations are greater than $5 \mathrm{mg} / \mathrm{l}$, and levels as low as $0.5 \mathrm{mg} / \mathrm{l}$ may be harmful to certain sensitive crops. For example, excessive chlorine residuals can have a leaf-burning effect when reclaimed water is sprayed directly onto foliage. This effect can be reduced by low-angle spray heads or certain surface irrigation options. 
Biochemical oxygen demand (BOD) is one of the most widely used water quality parameters; it indicates the amount of organic matter available to be decomposed by aerobic microorganisms. Regarding wastewaters, the higher the BOD, the stronger or more concentrated the waste (Penn, Pauer, and Mihelcic 2009). The EPA guidelines say that the treatment of reclaimed water for irrigation of nonprocessed food crops should achieve a BOD level of $10 \mathrm{mg} / \mathrm{l}$ or less. The maximum level is $30 \mathrm{mg} / \mathrm{l}$ for commercially non-processed food crops and non-food crops.

Total suspended solids (TSS) and turbidity (measured using nephelometric turbidity units, or NTUs) are measures of the amount of organic and inorganic particles that are present in the water column (Haering et al. 2009). For nonprocessed raw food crops, the recommended turbidity level is $2 \mathrm{NTU}$ or less, and it should never exceed 5 NTU. This level should be achieved prior to disinfection since it affects the effectiveness and dosage of the treatment. The average turbidity should be based on a time period of 24 hours. The average level of suspended solids should not exceed $5 \mathrm{mg} / \mathrm{l}$ if TSS is used in lieu of turbidity. Additionally, if the filtration process used is membranes, the turbidity level should not exceed 0.2 NTU, and the average level of suspended solids should not exceed $0.5 \mathrm{mg} / \mathrm{l}$. For processed food crops and non-food crops, TSS should not exceed $30 \mathrm{mg} / \mathrm{l}$.

The presence of fecal coliform bacteria in water is an indicator of fecal contamination. Therefore, lower levels of fecal coliforms are associated with higher disinfection efficiency. Identifying fecal contamination is an important part of the assessment of the quality and safety of agricultural water. Presence of fecal coliform bacteria increases the likelihood that disease-causing microorganisms are also present (FDA 2017). The requirements set by the US Food and Drug Administration (FDA) regarding the presence of Escherichia coli (E. coli, a species of fecal coliform bacteria) in agricultural water should also be considered. These rules are discussed in the next section, which discusses FDA requirements under the Food Safety Modernization Act.

The recommended limits are median results of the last 7 bacteriological analyses. Either a membrane filter or fermentation tube technique may be used. For non-processed food crops, there should be no detectable fecal coliforms per $100 \mathrm{ml}$ (median of last 7 samples). For processed food crops and non-food crops, 200 fecal coliforms per 100 $\mathrm{ml}$ is the maximum recommended level (median of last 7 samples). The number of fecal coliform organisms should not exceed $800 / 100 \mathrm{ml}$ in any sample.
For all crops, levels of $\mathrm{pH}$ and BOD should be monitored weekly; fecal coliform levels should be monitored daily, and chlorine residual levels should be monitored continuously. Levels of turbidity for non-processed food crops should be monitored continuously, while TSS monitoring should occur daily for processed food crops and non-food crops.

Setback distances are important because they protect potable water supply sources from contamination. For non-processed food crops, there should be a distance of 50 $\mathrm{ft}(15 \mathrm{~m})$ to potable water supply wells. This distance should be increased to $100 \mathrm{ft}(30 \mathrm{~m})$ when located in porous media. There are additional precautions that can be taken if it is not possible to achieve a setback distance of $100 \mathrm{ft}(30 \mathrm{~m})$ to potable water supply wells in porous media. A distance of $300 \mathrm{ft}(90 \mathrm{~m})$ to potable water supply wells is allowed for processed food crops and non-food crops. Additionally, there should be a distance of $100 \mathrm{ft}(30 \mathrm{~m})$ from areas accessible to the public if spray irrigation is used.

\section{The FDA Requirements under the Food Safety Modernization Act (FSMA)}

The FDA has set requirements for the quality of water when water is used for agricultural irrigation based on the premise that "all agricultural water must be safe and of adequate sanitary quality for its intended use." (FDA 2015). Growers using recycled water for food crop irrigation should consider these requirements. In response to the rise in incidents of foodborne outbreaks in fresh produce, the congress enacted the Food Safety Modernization Act (FSMA) in 2011. The act enables the FDA to better regulate the food system by focusing on preventing food safety problems rather than responding to incidents after they occur.

As part of the implementation of the FSMA, the FDA established science-based minimum standards for the safe growing, harvesting, packing, and holding of produce (fruits and vegetables) grown for human consumption. The "produce safety rule" (PSR) covers different factors that affect produce safety, such as worker training, biological soil amendments, and agricultural water. The specific microbial quality criteria for agricultural water used for irrigation are outlined in Subpart E of the document, which was published in 2015 and went into effect in 2016. When agricultural water is used during growing activities for produce using a direct application method, growers must ensure that there is no detectable generic E. coli in 100 $\mathrm{ml}$ of agricultural water. This means that the geometric mean concentration of generic E. coli should not exceed 126 colony-forming units (CFU) per $100 \mathrm{ml}$ of water. 
Additionally, the statistical threshold value (STV) should not exceed $410 \mathrm{CFU}$ of generic E. coli per $100 \mathrm{ml}$ of water. Bihn et al. (2017) published a document that outlines how to perform these mathematical calculations. These requirements do not apply to certain produce that is rarely consumed raw; produce that is used for personal or onfarm consumption; or produce that is not a raw agricultural commodity (RAC).

Testing requirements are different for untreated surface and groundwater since it is assumed that surface water is more vulnerable to contamination than ground water. There are different factors that may reduce testing frequency and cost for farmers. For instance, farms that use a public water system or supply are not required to test their water as long as there are documents showing that the public water meets the quality standards. Alternative microbial quality criteria can also be used under certain conditions.

\section{Florida Water Reuse Regulations}

Florida produces more reclaimed water than any other state in the country (FDEP 2019). In 2018, an average of 797 million gallons per day of reclaimed water was reused in Florida. This corresponds to an average daily per capita reuse of 38.23 gallons (FDEP 2020a). The Florida Legislature has established "the encouragement and promotion of reuse of reclaimed water and water conservation" as formal state objectives in Section 403.064(1), Florida Statutes (F.S.), and Section 373.250, F.S. (FDEP 2020b).

In Florida, reclaimed water reuse plays a vital role in statewide water resource management. First, it can help address water pollution issues. Nutrients (i.e., nitrogen and phosphorus), along with fecal indicator bacteria, are the leading causes of surface and groundwater impairment in Florida (FDEP 2020c). An increase in reclaimed water utilization can improve water quality by eliminating wastewater discharges into oceans, rivers, and other water bodies (EPA 2017). At the same time, careful management of irrigation and fertilizer application is needed to avoid excessive nutrient runoff from areas irrigated with reclaimed water. The concentration of nutrients in reclaimed water vary from utility to utility, but it is almost always higher than that in freshwater. Excessive irrigation with reclaimed water, combined with fertilizer application, can lead to nutrients escaping from the root zone and impacting the quality of surface or groundwater (Martinez et al. 2011; Hochmuth et al. 2016).
Second, reclaimed water utilization can help reduce the state's reliance on groundwater withdrawals. With documented reductions in the flows and levels of selected rivers, springs lakes, and aquifers (FDEP 2020d), groundwater withdrawals need to be reduced or offset by increasing groundwater recharge in many areas. Reclaimed water utilization can reduce groundwater withdrawals (e.g., when used for irrigation) and increase groundwater recharge (e.g., when applied to constructed wetlands).

In 1987, Florida implemented a program to promote water reuse in response to the state reuse objectives. A provision added to the Florida Administrative Code (F.A.C.) in 1988 required the Florida water management districts to designate Water Resource Caution Areas (WRCAs). WRCAs are areas that are projected to face critical water supply problems during the next 20 years. These areas are required to follow a mandatory reuse program unless there are economic, environmental, or technical feasibility issues (Takashi et al. 2007).

Like the EPA's "Fit for Purpose" approach, Florida is among the states that prescribe the required level of treatment for reclaimed water depending on the end use. Only $8 \%$ of the reclaimed water is used for agricultural irrigation (FDEP 2020a). While the use of reclaimed water for irrigation of public areas such as residences, parks, schools, and golf courses has increased significantly over the last two decades, representing over half of the total use, reclaimed water use flow for agricultural irrigation has declined from 90 million gallons per day (MGD) in 1990 to 64.8 MGD in 2016. Chapter 62-610 of the Florida Administrative Code, entitled "Reuse of Reclaimed Water and Land Application," contains the rules governing water reuse. This chapter was established in 1989 and has been revised in 1990, 1996, 1999, 2006, and 2007.

Table 3 summarizes the Florida regulations for water reuse for agricultural irrigation. Rule 62-610.475, F.A.C., establishes that edible crops that will be peeled, skinned, cooked or thermally processed before consumption are allowed to be irrigated with reclaimed water; direct contact of the reclaimed water with these crops is allowed. Other crops can be irrigated with reclaimed water only if an indirect application method is used; direct contact is not allowed. Irrigation of tobacco or citrus with reclaimed water is permitted, including citrus used for fresh table fruit. Monitoring requirements vary by plant capacity. Wastewater treatment facilities providing reclaimed water for crop irrigation must maintain an inventory of the commercial agricultural operations supplied and submit annual reports to the FDEP (FDEP 2019). 
Secondary treatment is the minimum requirement for all domestic wastewater facilities. While basic disinfection is deemed sufficient for processed food crops and non-food crops, high-level disinfection is required for non-processed raw food crops. Five-day carbonaceous biochemical oxygen demand $\left(\mathrm{CBOD}_{5}\right)$ requirements for secondary treatment are: the annual average shall not exceed $20.0 \mathrm{mg} / \mathrm{l}$; the monthly average shall not exceed $30.0 \mathrm{mg} / \mathrm{l}$; the weekly average shall not exceed $45.0 \mathrm{mg} / \mathrm{l}$; and the maximum-permissible concentration in any single sample shall not exceed $60.0 \mathrm{mg} / \mathrm{l}$ (62-600.420(3)(a), F.A.C.). Total Suspended Solids (TSS) requirements for secondary treatments are: the annual average shall not exceed $20.0 \mathrm{mg} / \mathrm{l}$; the monthly average shall not exceed $30.0 \mathrm{mg} / \mathrm{l}$; the weekly average shall not exceed $45.0 \mathrm{mg} / \mathrm{l}$; and the maximum-permissible concentration in any single sample shall not exceed 60.0 mg/l (62-600.420(3)(b), F.A.C.). However, for high-level disinfection, no sample shall exceed $5.0 \mathrm{mg} / \mathrm{l}$ of TSS at a point before application of the disinfectant (62-600.440(6) (a), F.A.C.).

Where chlorine is used for disinfection, the total chlorine residual that should be maintained after at least 15 minutes contact time at the peak hourly flow is of at least $0.5 \mathrm{mg} / \mathrm{l}$ for basic disinfection (62-600.440(5)(c), F.A.C.). This value increases to $1 \mathrm{mg} / \mathrm{l}$ for high-level disinfection (62$600.440(6)(b)$, F.A.C.).

For basic disinfection, the arithmetic mean of the monthly fecal coliform values shall not exceed 200 per $100 \mathrm{ml}$ of reclaimed water or effluent sample. The monthly fecal coliform values are calculated as the geometric mean of the fecal coliform values for a minimum of 10 samples of reclaimed water, each collected on a separate day during a period of 30 consecutive days. No sample shall exceed 800 fecal coliform values per $100 \mathrm{~mL}$ of sample (62-600.440(5) (a), F.A.C.). For high-level disinfection, the requirement is that $75 \%$ of the monthly fecal coliform values be below the detection limits. Additionally, no sample shall exceed 25 fecal coliform values per $100 \mathrm{~mL}$ of sample (62-600.440(6) (a), F.A.C.).

In addition to the requirements outlined above, there should be "readily identifiable" signs marking facilities where reclaimed water is being applied or distributed. Signs should say "non-potable" or "do not drink" in English and Spanish, together with the equivalent standard international symbols (62-610.468, F.A.C.).

\section{Conclusion}

While Florida has strict regulations regarding irrigation of crops with reclaimed water, it is still a feasible and cost-effective alternative for growers (Hazen and Sawyer 2010). In a survey conducted for the Southwest Florida Water Management District in 2010, 68\% of respondents (reclaimed water users in Florida, including farmers using reclaimed water for crop irrigation) agreed that reclaimed water provided a guaranteed and reliable water source, which meant that growers were able to conserve freshwater for other uses. Additionally, $63 \%$ of respondents said that they were able to irrigate more frequently (Hazen and Sawyer 2010).

There exists great potential for expansion of water reuse systems and applications in the United States. Other countries, such as Israel and Tunisia, have well-established water reuse programs for agricultural irrigation . Nearly $90 \%$ of wastewater in Israel is recycled, most of it (80\%) for agricultural irrigation. Farmer education and public awareness are important factors for the success and expansion of reclaimed water projects. This study supports Extension education on agricultural irrigation by presenting regulatory facts and limits on using reclaimed water in agriculture. Future research could analyze water quality data in light of these regulations to help identify specific regions where enforcement of water reuse regulations is more costly due to relatively more polluted water sources.

\section{Appendix: List of Definitions References}

Binh, E., B. Fick, D. Pahl, D. Stoeckel, K. Woods, and G. Wall. 2017. "Geometric Means, Statistical Threshold Values, and Microbial Die-Off Rates." Produce Safety Alliance, Cornell University.

EPA. 2012. "2012 Guidelines for Water Reuse.” EPA/600/R-12/618.

EPA. 2017. Water Recycling and Reuse: The Environmental Benefits. US EPA, Pacific Southwest, Region 9. https://19january2017snapshot.epa.gov/www3/region9/ water/recycling/\#p2

FAO. n.d. "Water at a Glance: the Relationship between Water, Agriculture, Food Security and Poverty." http://www. fao.org/3/ap505e/ap505e.pdf 
FDA. 2017. "How Did FDA Establish Requirements for Water Quality and Testing of Irrigation Water under the FSMA Final Rule for Produce Safety." https://www.fda. gov/food/food-safety-modernization-act-fsma/how-didfda-establish-requirements-water-quality-and-testingirrigation-water-under-fsma-final-rule

FDEP. 2019. "Reuse Inventory Database and Annual Report." https://floridadep.gov/water/domestic-wastewater/ content/reuse-inventory-database-and-annual-report

FDEP. 2020a. "Florida's Reuse Activities." https:// floridadep.gov/water/domestic-wastewater/content/ floridas-reuse-activities

FDEP. 2020b. "Florida's Reuse Program." https:// floridadep.gov/water/domestic-wastewater/content/ floridas-reuse-program

FDEP. 2020c. "2020 Integrated Water Quality Assessment for Florida: Sections 303(d), 305(b), and 314 Report and Listing Update." https://floridadep.gov/sites/default/ files/2020_IR_Master_FINAL\%20-\%20ADA.pdf

FDEP. 2020d. "2019 Statewide Annual Report on Total Maximum Daily Loads, Basin Management Action Plans, Minimum Flows or Minimum Water Levels, and Recovery or Prevention Strategies." https://floridadep.gov/dear/ water-quality-restoration/content/statewide-annual-report

Haering, K., G. Evanylo, B. Benham, and M. Goatley. 2009. "Water Reuse: Using Reclaimed Water for Irrigation." Virginia Cooperative Extension 452(014).

Havelaar, A. H., K. M. Vazquez, Z. Topalcengiz, R. Munoz-Carpena, and M. D. Danyluk. 2017. "Evaluating the U.S. Food Safety Modernization Act Produce Safety Rule Standard for Microbial Quality of Agricultural Water for Growing Produce." J Food Prot. 80 (11): 1832-1841. doi:10.4315/0362-028X.JFP-17-122

Hazen and Sawyer. "Economic Feasibility of Reclaimed Water to Users." https://www.hazenandsawyer.com/work/ projects/economic-feasibility-of-reclaimed-water-to-users/

Hochmuth, G., L. Trenholm, R. Rainey, E. Momol, C. Lewis, and B. Niemann. 2016. Maximizing the Benefits of Reclaimed Water for Irrigating the Landscape and Protecting the Environment. SL385. Gainesville: University of Florida Institute of Food and Agricultural Sciences. https://edis.ifas. ufl.edu/ss587
Lewis, J., and A. L. Wright. 2014. "Reclaimed Water Use for Edible Crop Production in Florida." U.S. Department of Agriculture, UF/IFAS Extension Service.

Martinez, C. J., M. W. Clark, G. S. Toor, G. J. Hochmuth, and L. R. Parsons. 2011. Accounting for the Nutrients in Reclaimed Water Used for Landscape Irrigation. AE479. Gainesville: University of Florida Institute of Food and Agricultural Sciences.

McDaniel, R. L., C. Munster, and J. Nielsen-Gammon. 2017. "Crop and Location Specific Agricultural Drought Quantification." Transactions of the ASABE 60(3).

Parsons, L. R., B. Sheikh, R. Holden, and D. W. York. 2010. "Reclaimed Water as an Alternative Water Source for Crop Irrigation." HortScience 45(11).

Parsons, L. R. 2019. "Agricultural Use of Reclaimed Water in Florida: Food for Thought." Journal of Contemporary Water Research \& Education 165 (1): 20-27.

Penn, M. R., J. J. Pauer, and J. R. Mihelcic. 2009. “Biochemical Oxygen Demand." Environmental and Ecological Chemistry Vol. II.

Postel, S. L. 2000. "Entering an Era of Water Scarcity: The Challenges Ahead." Ecological Applications 10(4).

Takashi, A., F. L. Burton, H. L. Leverenz, R. Tsuchihashi, and G. Tchobanoglous. 2007. "Water Reuse Issues, Technologies, and Applications." New York: Metcalf \& Eddy.

Toor, G., and M. Lusk. 2011a. "Reclaimed Water Use in the Landscape: What's in Reclaimed Water and Where Does It Go?" U.S. Department of Agriculture, UF/IFAS Extension Service.

Toor, G., and M. Lusk. 2011b. "Reclaimed Water Use in the Landscape: Frequently Asked Questions about Reclaimed Water" U.S. Department of Agriculture, UF/IFAS Extension Service.

U.S. Department of Energy. "Alternative Water Sources Maps." https://www.energy.gov/eere/femp/ alternative-water-sources-maps 
Table 1. Summary of EPA water reuse guidelines for agricultural irrigation (adapted from EPA 2012).

\begin{tabular}{|c|c|c|c|c|}
\hline Reuse Category & Treatment & Water Quality & Monitoring & Setback Distances \\
\hline $\begin{array}{l}\text { Nonprocessed food } \\
\text { crops }\end{array}$ & $\begin{array}{l}\text { - Secondary filtration } \\
\text { - Secondary } \\
\text { disinfection }\end{array}$ & $\begin{array}{l}\cdot \mathrm{pH}=6.0-9.0 \\
\cdot \leq 10 \mathrm{mg} / \mathrm{l} \mathrm{BOD} \\
\cdot \leq 2 \mathrm{NTU} \\
\cdot \text { No detectable fecal } \\
\text { coli/100 ml } \\
\text { - At least } 1 \mathrm{mg} / \mathrm{I} \mathrm{Cl}_{2} \text { residual }\end{array}$ & $\begin{array}{l}\text { - Weekly: } \mathrm{pH}, \mathrm{BOD} \\
\text { - Daily: Fecal coliform } \\
\text { - Continuously: Turbidity, } \mathrm{Cl}_{2} \\
\text { residuals }\end{array}$ & $\begin{array}{l}\text { - } 50 \mathrm{ft}(15 \mathrm{~m} \text { ) to potable water } \\
\text { wells; increased to } 100 \mathrm{ft} \text { ( } 30 \\
\text { m) when located in porous } \\
\text { media }\end{array}$ \\
\hline Processed food crops & \multirow{2}{*}{$\begin{array}{l}\text { - Secondary } \\
\text { disinfection }\end{array}$} & \multirow{2}{*}{$\begin{array}{l}\cdot \mathrm{pH}=6.0-9.0 \\
\cdot \leq 30 \mathrm{mg} / \mathrm{l} \mathrm{BOD}\end{array}$} & \multirow{2}{*}{$\begin{array}{l}\text { - Weekly: pH, BOD } \\
\text { - Daily: Fecal coliform, TSS }\end{array}$} & \multirow{2}{*}{$\begin{array}{l}\text { - } 300 \mathrm{ft}(90 \mathrm{~m}) \text { to potable water } \\
\text { wells } \\
\text { - } 100 \mathrm{ft}(30 \mathrm{~m}) \text { to areas } \\
\text { accessible to the public (if } \\
\text { spray irrigation) }\end{array}$} \\
\hline Nonfood crops & & & & \\
\hline
\end{tabular}

Table 2. Recommended water quality criteria for irrigation (adapted from EPA 2012).

\begin{tabular}{|c|c|c|}
\hline Constituent & $\begin{array}{l}\text { Max } \\
\text { concentration } \\
\text { (mg/l) }\end{array}$ & Remarks \\
\hline Aluminum & 5.0 & $\begin{array}{l}\text { Can cause nonproductiveness in acid soils, but soils at pH } 5.5 \text { to } 8.0 \text { will precipitate the ion and eliminate } \\
\text { toxicity }\end{array}$ \\
\hline Arsenic & 0.1 & Toxicity to plants varies widely, ranging from $12 \mathrm{mg} / \mathrm{l}$ for Sudan grass to less than $0.05 \mathrm{mg} / \mathrm{l}$ for rice. \\
\hline Beryllium & 0.1 & Toxicity to plants varies widely, ranging from $5 \mathrm{mg} / \mathrm{l}$ for kale to $0.5 \mathrm{mg} / \mathrm{l}$ for bush beans. \\
\hline Boron & 0.75 & $\begin{array}{l}\text { Essential to plant growth; sufficient quantities in reclaimed water to correct soil deficiencies. Optimum } \\
\text { yields obtained at few-tenths } \mathrm{mg} / \mathrm{l} \text {; toxic to sensitive plants (e.g., citrus) at } 1 \mathrm{mg} / \mathrm{l} \text {. Most grasses are tolerant } \\
\text { at } 2-10 \mathrm{mg} / \mathrm{l}\end{array}$ \\
\hline Cadmium & 0.01 & $\begin{array}{l}\text { Toxic to beans, beets, and turnips at concentrations as low as } 0.1 \mathrm{mg} / \mathrm{l} \text {; conservative limits are } \\
\text { recommended }\end{array}$ \\
\hline Chromium & 0.1 & $\begin{array}{l}\text { Not generally recognized as an essential element; due to lack of toxicity data, conservative limits are } \\
\text { recommended }\end{array}$ \\
\hline Cobalt & 0.05 & Toxic to tomatoes at $0.1 \mathrm{mg} / \mathrm{l}$; tends to be inactivated by neutral and alkaline soils \\
\hline Copper & 0.2 & Toxic to a number of plants at 0.1 to $1.0 \mathrm{mg} / \mathrm{l}$ \\
\hline Fluoride & 1.0 & Inactivated by neutral and alkaline soils \\
\hline Iron & 5.0 & Not toxic in aerated soils, but can contribute to soil acidification and loss of phosphorus and molybdenum \\
\hline Lead & 5.0 & Can inhibit plant cell growth at very high concentrations \\
\hline Lithium & 2.5 & $\begin{array}{l}\text { Tolerated by most crops up to } 5 \mathrm{mg} / \mathrm{l} \text {; mobile in soil. Toxic to citrus at low doses - recommended limit is } \\
0.075 \mathrm{mg} / \mathrm{l}\end{array}$ \\
\hline Manganese & 0.2 & Toxic to a number of crops at few-tenths to few $\mathrm{mg} / \mathrm{l}$ in acidic soils \\
\hline Molybdenum & 0.01 & Nontoxic to plants; can be toxic to livestock if forage is grown in soils with high molybdenum \\
\hline Nickel & 0.2 & Toxic to a number of plants at 0.5 to $1.0 \mathrm{mg} / \mathrm{l}$; reduced toxicity at neutral or alkaline $\mathrm{pH}$ \\
\hline Selenium & 0.02 & Toxic to plants at low concentrations and to livestock if forage is grown in soils with low levels of selenium \\
\hline $\begin{array}{l}\text { Tin, Tungsten, } \\
\text { and Titanium }\end{array}$ & - & Excluded by plants; specific tolerance levels unknown \\
\hline Vanadium & 0.1 & Toxic to many plants at relatively low concentrations \\
\hline Zinc & 2.0 & $\begin{array}{l}\text { Toxic to many plants at widely varying concentrations; reduced toxicity at increased pH ( } 6 \text { or above) and in } \\
\text { fine-textured or organic soils }\end{array}$ \\
\hline
\end{tabular}


Table 3. Summary of Florida regulations for water reuse for agricultural irrigation (adapted from EPA 2012).

\begin{tabular}{|c|c|c|}
\hline Reuse Category & Nonprocessed food crops & Processed food crops and nonfood crops \\
\hline Unit processes & $\begin{array}{l}\text { Secondary treatment, filtration, high-level } \\
\text { disinfection }\end{array}$ & Secondary treatment, basic disinfection \\
\hline $\begin{array}{l}\text { Chlorine disinfection } \\
\text { requirements, if used }\end{array}$ & $\begin{array}{l}\text { TRC }>1 \mathrm{mg} / \mathrm{l} ; 15 \text { minutes contact time at } \\
\text { peak hr flow }\end{array}$ & TRC $>0.5 \mathrm{mg} / \mathrm{l} ; 15$ minutes contact time at peak hr flow \\
\hline $\mathrm{CBOD}_{5}$ & $\begin{array}{l}\cdot 20 \text { mg/l (annual average) } \\
\text { - } 30 \text { mg/l (monthly average) } \\
\text {. } 45 \text { mg/l (weekly average) } \\
\text { • } 60 \text { mg/l (max.) }\end{array}$ & $\begin{array}{l}\cdot 20 \text { mg/l (annual average) } \\
\cdot 30 \text { mg/l (monthly average) } \\
.45 \text { mg/l (weekly average) } \\
\text { • } 60 \text { mg/l (max.) }\end{array}$ \\
\hline TSS & $5 \mathrm{mg} / \mathrm{l}$ (max.) & $\begin{array}{l}\cdot 20 \text { mg/l (annual average) } \\
\cdot 30 \mathrm{mg} / \mathrm{l} \text { (monthly average) } \\
.45 \mathrm{mg} / \mathrm{l} \text { (weekly average) } \\
.60 \mathrm{mg} / \mathrm{l} \text { (max.) }\end{array}$ \\
\hline Fecal coliform & $\begin{array}{l}\cdot 75 \% \text { of samples below detection } \\
\cdot 25 / 100 \mathrm{ml} \text { (max.) }\end{array}$ & $\begin{array}{l}\cdot 200 / 100 \mathrm{ml} \text { (average) } \\
\cdot 800 / 100 \mathrm{ml} \text { (max.) }\end{array}$ \\
\hline
\end{tabular}

Table 4. List of Definitions

\begin{tabular}{|c|c|}
\hline Alternative water source & $\begin{array}{l}\text { Salt water; brackish surface and groundwater; surface water captured predominately during wet-weather } \\
\text { flows; sources made available through the addition of new storage capacity for surface or groundwater, } \\
\text { water that has been reclaimed after one or more public-supply, municipal, industrial, commercial, or } \\
\text { agricultural uses; the downstream augmentation of water bodies with reclaimed water; stormwater; and } \\
\text { any other water supply source that is designated as nontraditional for a water supply planning region in } \\
\text { the applicable regional water supply plan }(\$ 373.019(1), \text { Fla. Stat.). }\end{array}$ \\
\hline $\begin{array}{l}\text { Biochemical oxygen demand } \\
\text { (BOD) }\end{array}$ & $\begin{array}{l}\text { A measurement of the amount of dissolved oxygen used by bacteria and other aerobic microorganisms } \\
\text { to decompose organic matter present in a given water sample. It is usually expressed in milligrams of } \\
\text { oxygen consumed per liter of sample during } 5 \text { days of incubation at } 20^{\circ} \mathrm{C} \text {. It is used as a measure of the } \\
\text { organic strength of wastes in water. }\end{array}$ \\
\hline Colony forming units (CFU) & $\begin{array}{l}\text { Unit that estimates the number of viable bacteria or fungal cells found in a sample. It can be used to } \\
\text { measure the presence of } E \text {. coli in a water sample. }\end{array}$ \\
\hline Crop & $\begin{array}{l}\text { A plant or plant product that is grown and harvested. Crops can be divided into two categories: food } \\
\text { crops and nonfood crops. Food crops are further divided into two categories within the context of } \\
\text { irrigation with reclaimed water: commercially processed food crops, and nonprocessed (raw) food crops. }\end{array}$ \\
\hline Freshwater & $\begin{array}{l}\text { Freshwater can be any naturally occurring water except seawater and brackish water. Freshwater is } \\
\text { generally characterized by having low concentrations of dissolved salts and other total dissolved solids. } \\
\text { Freshwater includes water in glaciers, icebergs, bogs, ponds, lakes, rivers, streams, and water from the } \\
\text { ground (groundwater). Freshwater is typically not suitable for drinking without some treatment. }\end{array}$ \\
\hline Pathogen & $\begin{array}{l}\text { An organism (microbe or microorganism such as a virus, bacterium, prion, or fungus) causing disease to } \\
\text { its host. Human pathogens cause disease in humans. Plant pathogens cause disease in plants. }\end{array}$ \\
\hline Reclaimed/recycled/reused water & $\begin{array}{l}\text { Former wastewater that has been recovered from domestic, commercial, and industrial sources } \\
\text { and has been treated to remove impurities so it can be reused for other beneficial purposes such as } \\
\text { agriculture and irrigation, potable water supplies, groundwater replenishment, industrial processes, and } \\
\text { environmental restoration. }\end{array}$ \\
\hline Residual chlorine & $\begin{array}{l}\text { Amount of chlorine remaining in the water after chlorination. The presence of free chlorine in water is } \\
\text { correlated with the absence of most disease-causing organisms and thus is a measure of the potability of } \\
\text { water (CDC n.d.) }\end{array}$ \\
\hline Total suspended solids (TSS) & $\begin{array}{l}\text { A measure of the presence of particles of different origins in the water column, including soils, metals, } \\
\text { organic materials and debris particles that are larger than } 2 \text { microns. }\end{array}$ \\
\hline Turbidity & $\begin{array}{l}\text { A measure of the degree to which the water loses its transparency due to the presence of suspended } \\
\text { particles. It is measured in Nephelometric Turbidity Units (NTU). }\end{array}$ \\
\hline
\end{tabular}

